\title{
APRESENTAÇÃO
}

\section{POLÍTICAS CURRICULARES: TECENDO DISCURSOS PLURAIS}

\author{
Maria Zuleide da Costa Pereira \\ Idelsuite de Sousa Lima
}

Com muita satisfação apresentamos o primeiro número da Revista Espaço do Currículo de 2015. Com isso, cumprimos a nossa missão de oportunizar que a produção científica sobre currículo seja divulgada, incentivando o debate acadêmico para a produção de novos conhecimentos.

A presente edição conta com a colaboração de renomados pesquisadores, o que é uma honra e um mérito poder dispor de artigos de tamanha relevância. Tais textos foram objeto de apresentação em conferências realizadas por ocasião de eventos promovidos pelo GEPPC, sendo grande parte oriunda do VI Colóquio internacional sobre políticas e práticas curriculares. Seguindo a temática do evento, parte dos textos versa sobre sentidos de educação e ensino, com suas ramificações e vertentes mais diversas.

A sessão especial assinada pela pesquisadora Rosane Evangelista Dias, apresenta 'Sentidos produzidos nas políticas curriculares de formação docente', em que discute políticas de formação de professores no Brasil e também no espaço ibero-americano. A autora ressalta que "investigar o currículo como uma política cultural pública implica procurar entender como ele se constitui a partir dos discursos que são forjados sobre a educação, a formação, a profissão, a avaliação, entre outros e as imbricações entre esses diferentes aspectos".

Dias destaca ainda a tensão existente entre os processos de negociação e articulação na luta pelas políticas de currículo, em que diferentes sujeitos políticos assumem determinadas posições nas arenas de decisão política, em torno de projetos que pretendem tornar hegemônicos.

Já Rita Amelia Teixeira Vilela, no primeiro artigo denominado 'Educação e ensino na materialização do currículo na sala de aula: evidências empíricas e desafios para a formação dos professores', defende que políticas de currículo e formação de professores não podem e não devem ser dissociados do conhecimento sobre o que ocorre nas práticas internas das escolas. Para a autora, os processos de formação docente devem possibilitar maior competência técnica e de conteúdo; domínio de conhecimento da teoria da educação como condição para que os professores assumam maior compromisso como o processo de escolarização e maior reflexão crítica sobre sua própria prática.

O segundo artigo, de Janssen Felipe da Silva aborda "Sentidos de avaliação da educação no ensino e no currículo na educação básica através dos estudos pós-coloniais latinoamericanos". O autor discute processos de colonização eurocêntrica, destacando a necessidade de compreensão da geopolítica do conhecimento e da educação e suas repercussões na constituição dos sentidos do currículo e da avaliação escolar.

Para autor, ainda que o sistema escolar seja um latifúndio epistêmico, cultural, político e social da elite burguesa, a cultura e a educação têm um papel imprescindível na resistência às imposições coloniais e na proposição de outras formas de vida. Defende que "a Colonialidade e a Decolonialidade se fazem e refazem mutuamente, cada uma delas traz em si elementos da outra que estão presentes no cotidiano escolar". 
Sob outra perspectiva, o artigo de Ângela Cristina Alves Albino, discute 'Políticas de autonomia na proposição do currículo projeto'. A autora afirma que há um currículo prescrito como modelo e referência para as escolas e um sistema de avaliação nacional que acompanha o desenvolvimento dessa prescrição, permeado pela busca de sua reformulação.

Destaca que há uma insistência em reformular documento, sem análise e participação de quem está 'na ponta', o que "tem sido um dos fatores que prefiguram um currículo esfacelado e distante da perspectiva de um currículo projeto". A autora considera que "o tempo do capital invade o tempo do trabalho e investe na transformação da escola pública numa 'organização' movida pelos princípios administrativos da gerência empresarial".

No quarto artigo, 'Reflexões sobre o currículo da Educação infantil e seus processos de educação e ensino: o currículo em ação nas creches', Ana Luisa Nogueira de Amorim problematiza uma questão em que há pouco consenso, relacionada com o estabelecimento de um currículo para a Educação Infantil.

A autora defende uma concepção de currículo como uma produção social e cultural, ao mesmo tempo em que afirma haver, na realidade pesquisada, um descompasso entre a Proposta e o currículo em ação nas creches. Defende a necessidade de um currículo para a educação infantil que considere a especificidade da ação educativa necessária às crianças pequenas, como forma "garantir que as crianças tenham acesso a uma educação infantil de boa qualidade".

As pesquisadoras Jocileide Bidô Carvalho Leite; Valéria de Matos Leitão de Medeiros tematizam 'Tensões no campo da política curricular da educação profissional técnica integrada ao Ensino Médio', apresentando resultado de uma pesquisa realizada em um Instituto Federal de Educação Ciência e Tecnologia. Constatam que o processo educativo pode fixar ou não sentidos no horizonte da perspectiva da democracia radical e plural, haja vista a incompletude e contingência das articulações em disputa.

As autoras reconhecem que "nos variados contextos socioculturais, os oponentes precisam ser encarados como adversários e não inimigos a serem eliminados, cuja existência precisa ser reconhecida como elemento significativo nos diferentes contextos das relações sociais e pode suscitar uma multiplicidade de formas de emancipações contingenciais".

Em seguida, no sexto artigo, José Luiz Ferreira, apresenta "O pensamento freireano e os sentidos de educação e ensino', em que revela proposições da contribuição das ideias de Paulo Freire para a prática educativa, particularmente para o currículo.

O autor destaca cinco assertivas a partir das quais a proposta freireana se estabelece no sentido de promover uma educação libertadora, quais sejam: um professor diferente; o respeito ao saber do educando; o diálogo como saber epistemológico; a educação como ato político; o exercício da curiosidade, da criatividade e da descoberta do mundo e de si. Defende que a pedagogia freireana "assenta-se na interação comunicativa cujo conhecimento se constrói no diálogo intersubjetivo".

Retomando a discussão sobre a Educação Infantil, Lenilda Cordeiro de Macêdo e Adelaide Alves Dias, no artigo "O currículo na pré-escola: novos e velhos sentidos de ensinar e de aprender", revelam resultados da tese de doutoramento realizada a partir de uma pesquisa de tipo etnográfica.

As autoras consideram que a fragilidade da proposta curricular e do próprio currículo em ação da pré-escola é também "consequência da fragilidade da política de formação continuada dos professores de educação infantil do município".

Por sua vez, Sandra Alves da Silva Santiago autoriza a publicação de 'Políticas públicas inclusivas na educação básica: refletindo sobre a situação do estudante surdo nas escolas de 
João Pessoa-PB. Reconhece os avanços das políticas públicas de inclusão, inclusive os avanços trazidos pelos textos legais. Porém, revela que na realidade pesquisada não há efetivação das "três modalidades previstas na lei: ensino de libras, ensino em libras e ensino de português. Além disso, a presença de intérprete em todas as turmas onde existam surdos não está garantida".

Para a autora, ainda que haja uma tendência no aumento de matrículas de pessoas surdas no ensino regular, a qualidade desta inserção social ainda é questionada no que diz respeito às reais possibilidades de aprendizagem para os sujeitos com deficiência auditiva.

A sessão Ensaios é contemplada com um artigo produzido a muitas mãos. Trata-se de 'Teorias e discursos no currículo: entre a teoria crítica e os discursos pós-críticos' assinado por Lindalva Gouveia Nascimento; Sawana Araújo Lopes; Kátia Valéria Ataíde e Silva; Maria Margareth de Lima; Ana Célia Silva Menezes. Neste artigo, as autoras buscam investigar principais concepções e discursos que marcaram o modo de pensar o Currículo nas teorias crítica e pós-críticas. Destacam o espaço de luta e de diferenças culturais que é a escola e o currículo em que diferentes sujeitos coabitam.

Concluem que "a transformação do Currículo é um processo de invenção do próprio currículo e, com isso, uma invenção de nós mesmos enquanto sujeitos". Afirmam que "entre a teoria crítica e os discursos pós-críticos existe uma disputa, tecida em rede complexa de significação - entre continuidades, contradições, tensões e rupturas - que pode favorecer a perspectiva de um currículo verdadeiramente plural, contextualizado e favorável às construções culturais democráticas".

Por fim, a revista apresenta duas resenhas. O texto Globalização e Educação, de Joao Lobo Antunes é resenhado por Edileuza Soares Diniz e Rafael Ferreira de Souza Honorato redige a resenha do livro o currículo como fetiche, de Tomaz Tadeu da Silva.

A Revista Espaço do Currículo deseja que os artigos aquí publicados ensejem questionamentos com a comunidade leitora, de modo a ampliar o debate do campo curricular.

Desejamos que esta edição contribua para o desenvolvimento de investigações científicas sobre o currículo, com vistas à produção de novos conhecimentos e o necessário questionamento dos saberes já produzidos. 